\title{
Paideusis
}

\section{"Learning and Social Difference: Challenges for Public Education and Critical Pedagogy" (Carmel Borg \& Peter Mayo)}

Ali A. Abdi

Volume 17, Number 1, 2008

URI: https://id.erudit.org/iderudit/1072469ar

DOI: https://doi.org/10.7202/1072469ar

See table of contents

Publisher(s)

Canadian Philosophy of Education Society

ISSN

0838-4517 (print)

1916-0348 (digital)

Explore this journal

Cite this review

Abdi, A. (2008). Review of ["Learning and Social Difference: Challenges for Public Education and Critical Pedagogy" (Carmel Borg \& Peter Mayo)].

Paideusis, 17(1), 67-69. https://doi.org/10.7202/1072469ar viewed online.

https://apropos.erudit.org/en/users/policy-on-use/ 
Paideusis, Volume 17 (2008), No. 1, pp. 67-69

Review of

\title{
Learning and Social Difference: Challenges for Public Education and Critical Pedagogy
}

by Carmel Borg \& Peter Mayo, Boulder, CO: Paradigm Publishers, 2005.

\author{
ALI A. ABDI \\ University of Alberta, Canada
}

The role of educators and educational researchers in critically interacting with the multi-located intersections of learning, difference and how, via the deployment of critical pedagogy, the function as well as the intentions of public education can be re-routed for the noble purposes of achieving inclusive public educational spaces cannot be overemphasized. Especially with the rapidity and the extensiveness of the processes of globalization, the mass movement of peoples across countries, seas and continents creates an instant call for the services of educational programs to suppress, indeed, fight against the increasing incidences of criminalizing difference when it selectively serves the life styles and social desires of dominant groups in one context or another. It is in relation to these global realities, but especially with respect to the Mediterranean area in general, and to Malta in particular that Carmel Borg and Peter Mayo situate their analysis and recommendations in this important work. While issues of difference and education and the needed critical pedagogy interventions have been studied and analyzed in the North American context for some decades now, the realities as well as the complexities of the growing difference in the public spaces of some European countries, both small (e.g., Malta) and relatively big (e.g., Italy) has not been discussed as much as it is needed in academic forums and related locations of knowledge construction and dissemination. But the issues both technically (i.e., in their physical characteristics) and socially (i.e., the constructive or disturbing relations that are created between the concerned agents) are not separable from basic educational and human rights pointers, and of course, by extension, form the overarching and fortunately globally expanding issues of ethically bound global citizenship. As such, Borg and Mayo's book is timely, historico-geographically of the right location, and humanistically needed.

Beyond an important foreword by the UCLA Professor and critical pedagogue, Peter McLaren and the introduction, the book consists of four sections: international and national policy issues; improving the face of schools and other pedagogical sites; critical pedagogy in international perspective; and challenges for critical pedagogy in a migratory context. The four sections collectively contain nine chapters, which with the introductory chapter give us a rich, well written and discursively inclusive descriptions and analyses that effectively, indeed, quite admirably, fulfill the promise of this work. In the introduction, which is subtitled, "Critical pedagogy in neoliberal times," the authors engage the essential (if not to be essentialized) role of public education to confront the growing technocratic learning dispensation of the neoliberal paradigm, which, as we should know by now, itemizes people's needs, rights and expectations into perpetually de-contextualizable calculations of whether the markets needs you or not. It is also with these market driven potential processes of instrumentalization that the depersonalization of one of the fundamental tenets of life, difference, may be relegated to the static and

(C) Copyright 2008. The author, Ali A. Abdi, assigns to Paideusis the right of first publication and educational and non-profit institutions a non-exclusive license to use this document for personal use and in courses of instruction provided that the article is used in full and this copyright statement is reproduced. Any other usage is probibited without the express permission of the author. 
pre-critical anthropology storehouses so it is, at will, applied to the lives of the politically and economically damned. Here, the need to go counter-this and harness the seminal works of, inter alia, Paulo Freire, Antonio Gramsci should be anticipated, and are not left unattended to, by Borg and Mayo. In chapter two, "The EU Memorandum on lifelong education: Old wine in new bottles," Borg and Mayo speak about the original meaning of the term "lifelong education," and discuss how it has been later subjected to the exclusionist turns of the economistic model, which at the end of the day, does not deconstruct the technicalization of learning possibilities, rendering the whole thing, in the process, a mere training project that advances the temporary skilling of those whose services may be required at one point or another.

In chapter three, "Social difference, cultural arbitrary and identity: An analysis of a national curriculum document in a non-secular environment," the focus is on the important social and cultural representations of school curricula with respect to the concerned societies and populations. Here, the critique is aimed at Malta's national curriculum, which contrary to the realities on the ground, seems to have previously disavowed the needed discussions of gender, race, disability and related categorizations of the given socio-historical context. With recent revisions, though, there have been some progressive steps achieved in this regard, but critical educators, it is recommended, should always be vigilant and beware of these possible omissions and commissions which could marginalize so many in the midst of the dominant collective. In chapter four, "Changing the face of the school: Parental involvement in a working-class community," the authors prospectively interrogate the habitualized assumption that working-class parents whose times and spaces are continuously colonized by the marauding exigencies of the market place, should still being expected to effectively respond to the schooling demands that are also structured to marginalize both these parents and their children. While that will always be difficult, the authors' research seems to indicate some possibilities of empowerment where parents understand and effectively interact with school environments. While that is good and nice, one needs to ascertain the long-term outcomes in terms of the overall social changes that take place in the lives of these communities.

In chapter five, "Museum education as cultural contestation," Borg and Mayo examine the potential of museums as educational sites. Here, because of the privileged social classes that usually benefited from both the contents and intentions of museums, one could think of the important possibilities to decolonize the pictorial and narrative characters of these institutions so as to re-socialize them into communally productive public spaces that serve the interests of the collective. To achieve that, the archaic exclusiveness of museums should be shattered, and new ways of increasing people's access to the place should be devised and implemented. In chapter six, "Gramsci and the Unitarian school: Paradoxes and possibilities," Antonio Gramsci's philosophy of education is discussed. That philosophy, as it was designed within the context of the Unitarian school, was to counter the deculturing realities of learning that kept working class pupils and their families on the periphery of the social order. As opposed to that, the Unitarian school, also known as the Common school, or school of humanistic formation was to "insert young men and women into social activity after bringing them to a certain level of maturity or capacity for intellectual and practical creativity, of autonomy of orientation and initiative" (p. 99). Clearly, such school will not be alien to the critical pedagogy contexts we need to achieve to localize and also internationalize the proactive citizenship consciousness that current learning programs should deploy with respect to the realities of the real and increasing social differences that surround us.

In Chapter seven, "Making sense of a Southern postcolonial context: A Freirean perspective," Borg and Mayo critically locate their Mediterranean postcolonial context with respect to Freire's now celebrated analysis. In so doing, the authors try to move away from the dominant Eurocentric discourses that have at one point, informed their own education and intellectual development. Here, the interactive spaces have to be busy, and would contain select socio-historical as well cultural notations and other evolving factors of people's lives in Malta and, by desired extension, elsewhere. For that to happen, though, critical educators should not miss the main destination of safeguarding the 
rights of each and every member of the differently located learning communities and their affiliations. In chapter eight, "Critical pedagogy and citizenship," the main focus is the work of Lorenzo Milani, whose agitations and writings thereof, especially his Lettera a un Professoressa were important in influencing the thinking of many people including the youth groups that challenged dominant systems in the late 1960s. Here, the authors give a succinct but analytically summative pointers on the life of Milani, who based on the opportunities he was born in, should have been doing other things than go against the system that privileged his family. As Gramsci, Milani's educational platform was to inform about citizenship, especially in relation to those whose learning and related rights were not being advanced by the general schooling system.

In chapter nine, "Toward an anti-racist agenda in education: The case of Malta," the analyses is on the changing realities of the Maltese social composition, and ways of establishing educational possibilities that counter the growing incidences of racism against those who are perceived as nonMaltese, especially Africans and Arabs. While the issue may not be covered by the media as much as it should, the authors note it is, nevertheless, something that is now fully attached to the Maltese public space. Here, the rising rates of migration from poor countries in Africa, which is not unrelated to the general trends of globalization that are happening everywhere, makes Malta, a small island located between Africa and Europe, an important transit area for many who are fleeing poverty and lack of opportunities in their own countries. Expectedly some of those who cannot leave Malta to reach continental Europe may not also be able to go back home either, establishing in the process a huge contingent of 'unwanted' migrants and refugees, who may be victimized on the separate but combinable platforms of racism and Islamophobia. In the last chapter, Borg and Mayo talk about the important role of critical pedagogy and how it should deal with challenges of a changing world context where Southern Europe has become one of the most active areas in terms of inter-group interactions and all the ensuing differences that are inherent in the personalities, experiences and expectations of all those who must share a place for some reason or another. At the end of the chapter, the authors provide important recommendations that should humanize the space between migrants and those in the receiving countries, with schools becoming progressively designed sites of learning that are inclusive and welcoming for all.

In sum, this is a well designed work that responds to the important educational exigencies of our times, and although the discussions may be mostly specific to Malta, the crust of the story is also directly related to the increasingly difference-borne transformations we are continuously dealing with in our world. At the centre of this work, therefore, is a global call for strong platforms of critical pedagogy that appreciate difference and enhance its capabilities to strengthen societies and communities. The book should be widely read and referenced, and its overall contributions and topical implications should appeal to students and researchers in the educational and social sciences as well as those in related subjects of study. 